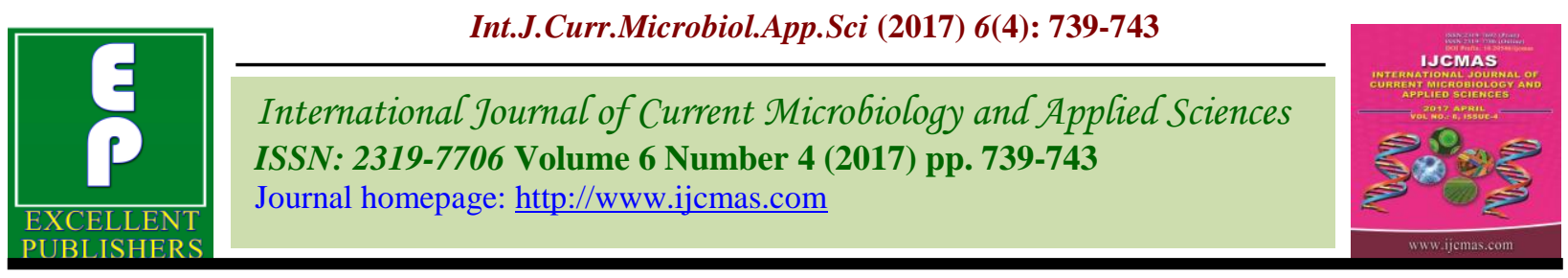

Original Research Article

https://doi.org/10.20546/ijcmas.2017.604.091

\title{
Adoption of Mungbean Production Technology by the Farmers in Jaipur District of Rajasthan, India
}

\author{
Mukesh Choudhary $^{1 *}$, Hanuman Lal Jat ${ }^{1}$, Seeta Bijarniya ${ }^{2}$ and Vidya Bhati ${ }^{3}$ \\ ${ }^{1}$ Department of Extension Education, Sri Karan Narendra College of \\ Agriculture, Jobner (Rajasthan)-303329, India \\ ${ }^{2}$ SRF D.E.E. SKNAU, Jobner, India \\ ${ }^{3}$ Department of Horticulture, SKRAU Bikaner, India \\ *Corresponding author
}

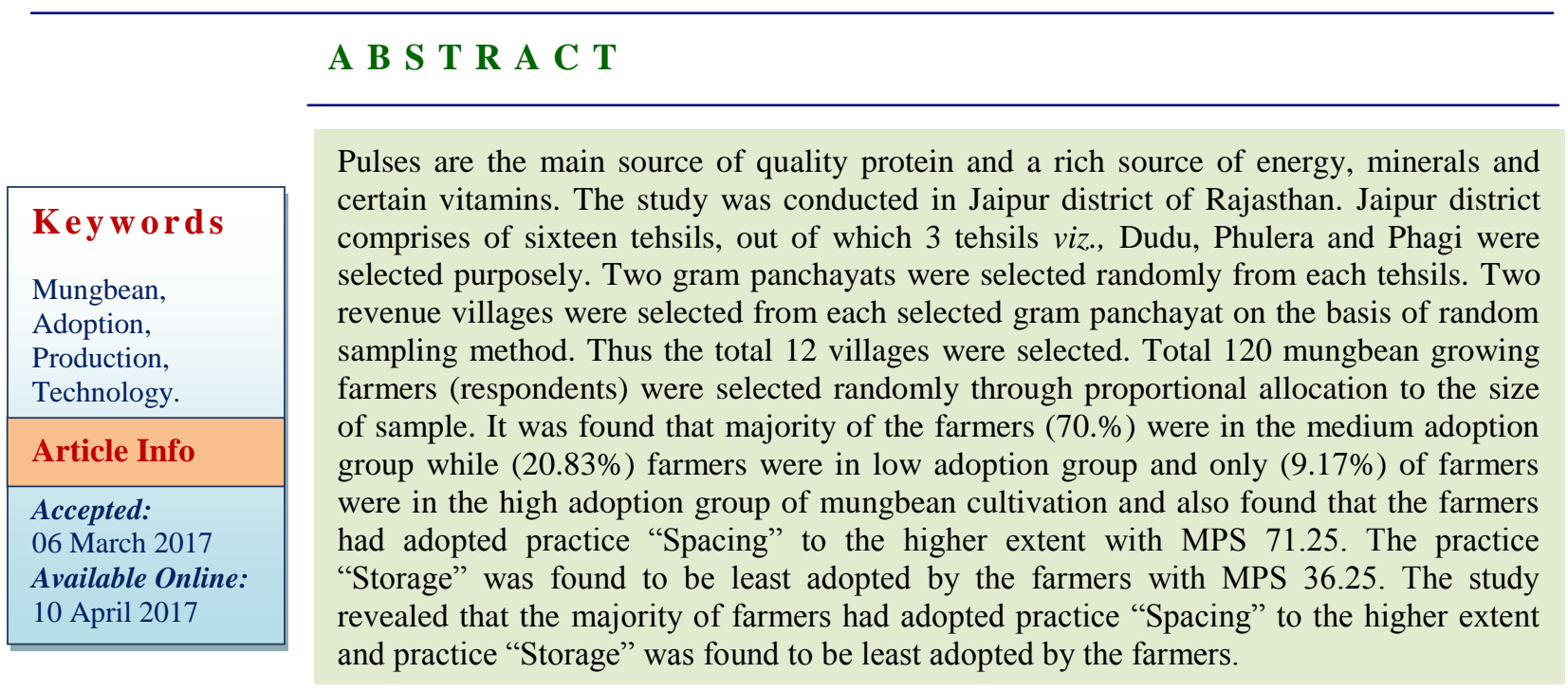

\section{Introduction}

Pulses are the main source of quality protein and a rich source of energy, minerals and certain vitamins. They help in balancing the cereal dominated diet of low and middle income families by supplementing the essential amino acids profile of cereal proteins economically.

Among the various legume crops grown in India mungbean occupies an important place because of its 25 percent protein excellent quality and high digestibility due to low flatulence (Singh et al., (1983). Providing balanced ration to the growing population of India Mungbean is a good option because of its high yielding potential. A quantum jump in the production of this crop can meet the expectations of the policy makers and nutritional planners.

Mungbean stands third after chickpea and pigenpea in the country among pulses. Pulses accounts $24.79 \mathrm{~m}$ ha area with an annual production of 19.77 million tons in the country. Mungbean occupies 29.36 lakh hectare area and contributes 12.80 lakh tones 
in pulse production in the country (Anonymous, 2012-13). The important mungbean growing states are Rajasthan, Madhya Pradesh, Uttar Pradesh, Orisha, Maharastra, Karnataka, Bihar etc.

In Rajasthan mungbean is grown over 790185 hectare with the production of 23426 tonnes. Jaipur district has 60624 hectare area under mungbean cultivation and production 9579 tonnes, which is nearly 4.09 per cent of total mungbean production in Rajasthan (Annoymous, 2012-13).

The productivity of Jaipur district is 158 $\mathrm{kg} / \mathrm{ha}$. There is a wide scope to improve and increase the mungbean production and productivity by enhancing the knowledge and adoption of recommended production technology by farmers.

\section{Materials and Methods}

The study was conducted in Dudu, Phagi and Phulera tehsils of Jaipur district of Rajasthan. Jaipur district was selected purposely on account of lowest productivity i.e. $158 \mathrm{~kg} / \mathrm{ha}$ and tehsils were selected purposely because these tehsils have maximum area under mungbean crop in Jaipur district, Farmers were selected on the basis of proportinate random sampling technique from each selected village making a total sample of 120 mungbean growers.

An interview schedule consisting of measuring devices along with the face data of the respondents was developed for the study purpose and was personally introduced to the respondents following the principles of interviewing.

The data so collected were tabulated and analyzed. Interferences were drawn after subjecting the data to statistical analysis which led to the following findings.

\section{Extent of adoption of production} technology practices of mungbean

To measure the extent of adoption on the three point continuum schedule developed by the investigator was used Ten package of practices of mungbean cultivation were included in the schedule. Some of the practices were further divided into subquestions. Finally the adoption index was calculated by the following formula:

Adoption Index $=$

Total adoption score obtained by respondents

Maximum attainable score

The formula was applied for all practices, which helped in calculating adoption index.

The mean and standard deviation of all the respondent adoption scores were computed for classifying the adoption in different categories. Based on the mean adoption score and standard deviation the farmers were categorized under three adoption level categories, namely low, medium and high adoption level as follows:

$\begin{aligned} & \text { Low adoption level } \\ & \text { (mean adoption }-\mathrm{SD})\end{aligned} \quad=$ Score below
$\begin{aligned} & \text { Medium adoption level } \\ & (\text { mean adoption }-\mathrm{SD}) \text { to }(\text { mean }+ \text { SD })\end{aligned}$
$\begin{aligned} & \text { High adoption level } \\ & (\text { mean adoption }+\mathrm{SD})\end{aligned} \quad=$ Score above

Extent of adoption of Production Technology practices of mungbean by the farmers

Adoption is a mental process. In recent times, a number of innovations are being generated by our agricultural scientists but all the innovations are not being adopted by the members of the social system. Adoption of an 
innovation depends upon the knowledge of adopters about innovations, innovativeness, complexity, visibility and capability of innovations. It is generally accepted that if an individual has knowledge about different aspects of technologies, he is likely to adopt it with high speed and high adoption rate. Therefore, adoption of technology becomes the central concern for social scientists. Thus the objective pertaining to adoption of recommended mungbean production technology included in the present investigation.

To get an over view of the adoption level of the farmers about recommended cultivation practices of mungbean the farmers were grouped into (i) low (ii) medium and (iii) high adoption categories on the basis of calculated mean and standard deviation of the obtained adoption scores by the respondents.

\section{Overall adoption level of farmers about recommended production technology mungbean}

The findings reveal that 84 respondents (70.00 per cent) fall in medium adoption category, whereas, 25 respondents (20.83 per cent) were found in low adoption and remaining 11respondents (9.17 per cent) possessed high adoption about recommended cultivation practices of mungbean given in table 1 (Sachan et al., 2005; Meena et al., 2006 and Kumari et al., 2006).

It was found that majority of the respondents (70.00 per cent) were medium adopters, 20.83 per cent were low adopters and only 09.17 per cent of the respondents were high adopters of recommended technology of mungbean cultivation. It may be due to the fact that various extension activities like demonstrations, trainings etc. are frequently organized by the extension field functionaries in the villages which might help in convincing the farmers about the recommended technology of mungbean cultivation, which have resulted in increasing the adoption of recommended technology by the farmers. Still there is an increasing recognition of the need to convert these medium adopters into high adopters and low adopters into medium adopters. Therefore, all the essential supplies and services for transfer of technology through extension activities should be made available to the farmers and an intensive effort to convince the farmers about recommended technology of mungbean is needed. The findings of the study are in accordance with the findings of (Solanki et al., 2012; Singh et al., 2006 and Rahim, 2003).

\section{Practice wise adoption by farmers about recommended production technology of mungbean}

The level of adoption of farmers was measured for ten mungbean cultivation practices. Efforts were made to include only those practices which can be adopted by the farmers practically in the field. The results have been presented in table 2 .

Table 2 shows that farmers had highest adoption about "spacing practice" in mungbean MPS 71.25 while minimum adoption was about "Storage" MPS 36.25. The table further indicates that the farmers adoption about fertilizer application, use of high yielding varieties, sowing of seed, soil and field preparation, harvesting, seed treatment, weed management and plant protection measure, were found with MPS 65.48, 62.50, 58.47, 46.80, 43.75, 43.16, 42.77 and 41.25 respectively Agarwal (2000). 
Table.1 Extent of adoption of recommended production technology of mungbean by the farmers

$\mathrm{N}=120$

\begin{tabular}{|c|l|c|c|}
\hline S. No. & Adoption categories & $\begin{array}{c}\text { Number of } \\
\text { respondents }\end{array}$ & Percentage \\
\hline 1 & Low (Score below 29.05) & 25 & 20.83 \\
\hline 2 & Medium (Score from 29.05 to 37.30) & 84 & 70 \\
\hline 3 & High (Score above 37.30) & 11 & 9.17 \\
\hline
\end{tabular}

$\bar{X}=33.18, \quad \sigma=4.12$

Table. 2 Practice wise adoption by farmers about recommended production technology of mungbean

$\mathbf{N}=\mathbf{1 2 0}$

\begin{tabular}{|c|l|c|c|}
\hline S.N. & Package of practices & MPS & Rank \\
\hline 1. & Soil and field preparation & 46.80 & V \\
\hline 2 & Spacing & 71.25 & I \\
\hline 3. & Use of high yielding varieties & 62.50 & III \\
\hline 4. & Sowing of seed & 58.47 & IV \\
\hline 5. & Seed treatment & 43.16 & VII \\
\hline 6. & Fertilizer application & 65.48 & II \\
\hline 7. & Weed management & 42.77 & VIII \\
\hline 8. & Plant protection measures & 41.25 & IX \\
\hline 9. & Harvesting & 43.75 & VI \\
\hline 10. & Storage & 36.25 & X \\
\hline
\end{tabular}

The farmers had over adopted the "Spacing" and "Fertilizer application" technology. The over adoption of "Spacing" practice might be due to the reason that the farmers had large size of land holding and they want to produce more. The over adoption of "Fertilization application" might be due to the reason that the farmers have know the importance of fertilizer application which resulted in highest adoption. The farmers had poorly adopted the practices like "Plant protection measures", "Weed management", "Storage " etc. might be due to high cost of weedicides, insecticides and pesticides and storage facilities. The findings of present study are in line with the findings of Singh (2010) and Chandawat et al., (2012) Solanki et al., (2012).

In conclusion it was found that majority of the farmers $(70 . \%)$ were in the medium adoption group while $(20.83 \%)$ farmers were in low adoption group and only (9.17\%) of farmers were in the high adoption group of mungbean cultivation and also found that the farmers had adopted practice "Spacing" to the higher extent with MPS 71.25. The practice "Storage" was found to be least adopted by the farmers with MPS 36.25. The study revealed that the majority of farmers had adopted practice "Spacing" to the higher extent and practice "Storage" was found to be least adopted by the farmers.

\section{References}

Agarwal, J.K. 2000. "Knowledge and adoption of improved pea cultivation practices in Jaipur district of Rajasthan”. M.Sc. (Ag.) Thesis, R.A.U., Bikaner, Campus: Jobner.

Annoymous. 2012-13. "Department of Agriculture and Corporation" 
Annoymous. 2012-13. "Vital Agriculture statistics, Directorate of Agriculture", Government of Rajasthan.

Chandawat, M.S., Sharma, P.K. and Parmar, A.B. 2012. "Extent of Adoption about Improved Cultivation Practices of Gram Crop and Constraints Faced by the Farmers of Kheda District" Guj. J. Extn. Edu., 23.

Kumari, N., Sharma, F.L. and Sharma, V.P. 2006. Adoption behaviour of garlic growers in Chittorgarh district of Rajasthan. Raj. J. Extn. Edu., 14: 36-40.

Meena, R.P., Sharma, C., Sharma, V.P., Bhimawat, B.S and Dadheech, B.S. 2006. Adoption of improved Ajwain production practices among the farmers of Dungla Tehsil in Chittorgarh district of Rajasthan. Raj. J. Extn. Edu., 14: 4751.

Rahim, F. 2003. "Impact of education level on the adoption of improved gram cultivation practices in Tehsil Takht-iNasrati, Karak, NWFP" Sarhad J. Ag, 19(3): 413-417.
Sachan, R.C., Sharma, A.K. and Jha, S.K. 2005. "Problem and strategy for mustard production in Bharatpur district of Rajasthan". Ind. Res. J. Extn. Edu., 5(1): 18-25.

Singh, B. Chauhan, T.R. 2010. "Adoption of mungbean production technology in arid zone of Rajashtan". Ind. Res. J. Extn. Edu, Vol. 10 No. 2 pp. 73-77.

Singh, C., Singh, P., Singh, R. 1983. Modern Technique of Raising Field Crops Oxford and IBH Publishing, (2): 244.

Singh, N., Lal, H. and Sharma, P. 2006. Adoption of recommended mustard production technology by the farmers. Raj. J. Extn. Edu., 10: 88-92.

Solanki, J., Solanki, K.D. and Mayur Prajapati. 2012. Extent of Adoption of Recommended Kidney Production Technology Guj. J. Extn. Edu, 23.

Solanki, J., Solanki, K.D. and Mayur Prajapati. 2012. Extent of Adoption of Recommended Kidney Production Technology, Guj. J. Extn. Edu., 23.

\section{How to cite this article:}

Mukesh Choudhary, Hanuman Lal Jat, Seeta Bijarniya and Vidya Bhati. 2017. Adoption of Mungbean Production Technology by the Farmers in Jaipur District of Rajasthan. Int.J.Curr.Microbiol.App.Sci. 6(4): 739-743. doi: https://doi.org/10.20546/ijcmas.2017.604.091 